\title{
SEED BANK IN TWO SITES OF SEMIDECIDUOUS SEASONAL FOREST IN VIÇOSA, MINAS GERAIS ${ }^{1}$
}

\author{
Antonio Jorge Tourinho Braga ${ }^{2 *}$, Eduardo Euclydes de Lima e Borges ${ }^{3}$ and Sebastião Venâncio Martins ${ }^{3}$ \\ ${ }^{1}$ Received on 31.07.2014 accepted for publication on 01.12.2015. \\ ${ }^{2}$ Instituto Federal de Educação, Ciência e Tecnologia Baiano, Campus Catu, Catu, BA-Brasil.E-mail:<antonio.braga@catu.ifbaiano.edu.br> \\ ${ }^{3}$ Universidade Federal de Viçosa, Centro de Ciências Agrárias, Viçosa, MG - Brasil. E-mail: <elborges@ufv.br > and < venancio@ufv.br>. \\ *Corresponding author.
}

\begin{abstract}
Aimed of this study was examine, describe and confronted the floristic composition and the density the seed bank in two successional stages of Seasonal Semideciduous Forest, in Viçosa, MG. Forty soil samples total in two distinct period (drought station finish and rainy station finis) and arranged for germinate in wooden boxes $(0,5 \times 0,5 \times 0,1 \mathrm{~m})$ in shading of $60 \%$. The individual germination in each valuation epoch was compared utilizing the $t$ test for independent samples; the test indicated one individual plants germination major in seed bank levy intermediary between epoch drought station finis and rainy station. Hundred nine taxons were sampled in the seed bank the forest altogether, 101 species were identified as belonging to 73 genera distributed among 40 families, 56 species commonness in two successional stages of forest and 49 species commonness of two levy period. Asteraceae was the families with the largest number of species as initial forest much as advanced forest, in both period of valuation. The herbaceous individuals predomination in all forests and valuation epoch, whit not representation the fragility of the seed bank.
\end{abstract}

Keywords: Soil seed bank; Similarity floristic of seed bank; Semideciduous Seasonal Forest.

\section{BANCO DE SEMENTES EM DOIS ESTÁDIOS SUCESSIONAIS DE UMA FLORESTA ESTACIONAL SEMIDECÍDUA EM VIÇOSA, MG}

RESUMO - O estudo teve por objetivo verificar, descrever e comparar a composição florística e a densidade do banco de sementes de dois estádios sucessionais de uma Floresta Estacional Semidecidual, em Viçosa/ MG. Foram coletadas, no total, 40 amostras de solo em dois periodos distintos (final da estação seca e da chuvosa), e colocadas para germinar em caixas de madeira sob $60 \%$ de sombreamento. Os individuos germinados em cada época de avaliação foram comparados utilizando o teste t para amostras independentes, o qual apontou uma maior germinação de indivíduos no banco de sementes coletado na época de transição entre estações seca e chuvosa. Foram identificados 109 táxons no banco de sementes da floresta como um todo, sendo reconhecidas 101 espécies distribuidas em 73 gêneros de 40 famílias. Ocorreram 56 espécies comuns aos dois trechos de floresta e 49 espécies comuns aos dois periodos de coleta. Asteraceae foi a família que apresentou maior número de espécies, tanto na floresta inicial como avançada, nas duas épocas avaliadas. Os individuos herbáceos predominaram nas florestas e épocas de avaliação.

Palavras-chave: Banco de sementes do solo; Similaridade florística do banco de sementes; Floresta Estacional Semidecidual. 


\section{INTRODUCTION}

The soil seed bank plays a key role in the dynamic equilibrium of the environment, acting directly on the vegetation recolonization of disturbed ecosystems (SCHMITZ, 1992). Acting as a reservoir of viable seeds which do not germinate usually in a state of primary or secondary dormancy, which is formed in the soil by deposition species from seeds of the local community of neighboring or distant areas, carried by different spreading processes that will affect the distribution of propagules (HARPER, 1977; HALL; SWAINE 1980; JOLY, 1986).

The time period in which seeds remain in the seed bank is determined by physiological factors that control the germination, dormancy and viability of seeds, also by environmental factors that influence such as moisture, temperature, luminosity and presence of predators and pathogens (GARWOOD, 1989).

The seed bank is a dynamic system, which is involved in regeneration processes and restoration of ecosystems, and their use can speed up and ensure the dynamics of successional process, recovering degraded environment (Braga et al., 2008). Inasmuch as their mechanism of action be improved when handled in a manner consistent with seral stage, always considering their density characteristics and floristic (ARAÚJO et al., 2001).

This large capacity of the bank in restoring plant communities has aroused the interest of researchers in order to better understand the dynamics of action (LONGHI et al., 2005; SOUZA et al., 2006; BRAGA et al., 2007, 2008; MARTINS et al., 2008; CALEGARI et al., 2013) or through knowledge of the floristic composition or its mechanisms of formation and germination, fundamental for conservation programs, management and environmental recovery.

Therefore, this study aims to determine, describe and compare the floristic composition and density of seed bank of two successional stages of Semideciduous Forest, located in the city of Viçosa, MG.

\section{MATERIALAND METHODS}

The study was conducted in a forest fragment called Forest Agronomy, which has approximately 50 ha and is located in an urban area on the campus of the Federal University of Viçosa, in Viçosa, Zona da
Mata of Minas Gerais (20 $46^{\prime} \mathrm{S}$ and $42^{\circ} 52$ 'W), at an altitude varying between $688-782 \mathrm{~m}$. The local topography is rugged, with narrow and humid valleys, predominantly Latossolo, which occurs at the top and on the slopes of elevations; and Ultisol, the terraces (CORREA, 1983). The climate through the Koppen system is the Cwb type, mesothermal with rainy summers and cold, dry winters. The average annual temperature is $19^{\circ} \mathrm{C}$ and relative humidity ranges around $80 \%$, with an average annual rainfall of 1,314 $\mathrm{mm}$ (CASTRO et al., 1983).

The Agronomy Forest vegetation is characterized as Semideciduous Forest Montana (VELOSO et al., 1991), forming a mosaic of different successional stages. The Forest has over 50 years of natural regeneration, established after the original vegetation has been replaced by the clearcutting by sequential planting of coffee, eucalyptus and pasture.

For the study were chosen two passages in different regeneration stages. The first is called initial forest $\left(20^{\circ} 46.105^{\prime} \mathrm{S}\right.$ and $\left.42^{\circ} 52.026^{\prime} \mathrm{W}\right)$ and the second forest advanced $\left(20^{\circ} 46.197^{\prime} \mathrm{S}\right.$ and $\left.42^{\circ} 52.061^{\prime} \mathrm{W}\right)$, and altitude range 688-737 I 708-782 $\mathrm{m}$ respectively. Both had the same history of disturbance, differentiating as to regeneration, which occurred at different times.

Sampling of seed bank was held on 10 permanent plots allocated in each section of the forest, according to the plot method (MUELLER-DOMBOIS; ELLENBERG, 1974 ), measuring $10 \times 25 \mathrm{~m}$, allocated systematically at intervals of $5 \mathrm{~m}$, with a total sample area of 0.5 ha, which served for the floristic and phytosociological study (BRAGA et al., 2011).

The soil samples were collected randomly in each plot using jigs $0,25 \times 0,25 \mathrm{~m}\left(0,0625 \mathrm{~m}^{2}\right)$, placed on the ground surface, first removing litter and then under this soil to a depth of $5 \mathrm{~cm}$, using a dustpan, a total of 20 samples, each consisting of four replicates. The collected material was placed in labeled plastic bags. The collection of the soil samples were taken in two periods, one in September, the time of transition between the dry and rainy seasons, the other in April, the time of transition between rainy and dry seasons.

The samples were transported to the Nursery Research of the Department of Forestry (UFV / MG), and placed in 20 wooden boxes of $50 \times 50 \times 10 \mathrm{~cm}$ format, totaling a $5 \mathrm{~m}^{2}$ area in each period. The boxes were 
filled with the collected soil and covered with litter then distributed over shaded stands $60 \%$. The irrigations were performed according to the weather conditions of the day, in order to avoid the stress of drought. Every month, over a period of one year was made to count and identify the plantlets from the soil seed bank.

The species identification was made through bibliographic queries in the literature and with the help of expert researchers. The species were presented according to the Angiosperm Phylogeny Group II system (APG II, 2003). The confirmation of the names of the species and its authors was obtained by consulting the site Missouri Botanical Garden (http:// www.mobot.org) and through specialized literatures.

The species were classified as the way of life (tree, shrub, liana and herbaceous) and tree species classified in the following categories in succession successional categories, according to the criteria adopted by Gandolfi et al. (1995), and classifications adopted in the studies of Martins and Rodrigues (2002) and Martin et al. (2002). Floristic comparison between the seed bank and the studied forest stretches was performed by developing a matrix of presence and absence of species and, from this, we built a dendrogram of similarity between all initial and advanced forest plots with all species sampled using Fitopac 1 program (SHEPHERD, 1996). For the preparation of the dendrogram were used the Jaccard similarity index (PIELOU, 1975) and the method of grouping the group average (UPGMA).

\section{RESULTS}

The seed bank presented in the two sampling periods the total of 2651 seeds germinated in both stretches of forest (initial and advanced). Were 1547 species germinated in the transition period between dry and rainy seasons ( 1 st collection), and 823 species in the initial forest and 722 in advanced forest and 1104 species germinated in the transition period between the rainy and dry season ( 2 nd collection) of these, 539 species were the bank's initial forest and 565 species of advanced forest. Therefore, the number of germinated seeds at the end of the dry season was significantly higher $(p=0.0000002)$ that germinated the seed bank collected at the end of the rainy season (Table 1 ).

In total they were identified 109 taxa in the forest seed bank as a whole, that were recognized 101 species in 73 genera of 40 families, 14 you identify solely on gender level, 10 at the family level, and eight remained undetermined. There were 56 species common to the two stretches of forest and 49 species common to the two collection periods. The initial forest presented 21 exclusive species in sample of the seed bank and 15 species in sample, while in advanced forest were 23 unique species in sample and 13 in the second (Table 1).

In the initial forest were recognized 64 species belonging to 29 families at the end of the dry season, four unidentified species, and 56 species of 23 families, with a species was not identified in the seed bank of the end of the rainy season, while the advanced forest were 61 species belonging to 24 families remaining four species not identified in the corresponding sampling at the end of the dry season and 52 species of 20 families, getting four species without identifying the end of the rainy season.

The richest family wealth specifies the seed bank was Asteracea, with 26 species, followed by Melastomataceae and Solanaceae both with eight species. The Asteraceae presented the highest number of species both in the initial forest as advanced in both periods evaluated.

The seed bank collected at the end of the dry season most individuals and species were herbaceous, followed by arboreal, both in the initial forest and in advanced. The same behavior was observed in the second collection of the bank corresponding to the end of the rainy season in both sections surveyed (Figure 1).

The largest number of individuals (160) and species (12) liana was observed in the initial forest compared to the advanced forest ( 27 individuals from 07 species), while the germination of these individuals in the initial forest was greater in the corresponding seed bank the end of the dry season (113 or $71 \%$ ).

The 461 sampled and identified individual trees belonged to 31 species of 20 families remaining three individuals without identification. In the initial forest were 160 individuals germinated the first collection distributed in 20 species of 13 families, in the second collection were sampled 56 individuals in 16 species of eight botanical families.

However, the largest number of individuals and species occur in advanced forest, where they were identified 159 individuals in the bank collected at the end of the dry season, there were 26 species of 14

Revista Árvore, Viçosa-MG, v.40, n.3, p.415-425, 2016

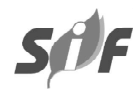


Table 1 - Germinated species in the seed bank collect in drought station finish ( $1^{\mathrm{a}}$ levy) and rainy ( $2^{\mathrm{a}}$ levy) of in the Mata da Agronomia in Viçosa, MG, and their respective life forms (FV) and sucessional classification: PI= pioneering specie, $\mathrm{SI}=$ initial secondary specie, $\mathrm{ST}=$ late secondary specie and $\mathrm{SC}=$ non classified.

Tabela 1 - Espécies germinadas no banco de sementes coletados no final da estação seca (1 ${ }^{a}$ coleta) e chuvosa $\left(2^{a}\right.$ coleta) nos dois trechos da Mata da Agronomia em Viçosa, MG, e respectivas formas de vida (FV) e classificação sucessional (CS): $P I=$ espécie pioneira, $S I=$ espécie secundária inicial, $S T=$ espécie secundária tardia e $S C=$ sem caracterização.

\begin{tabular}{|c|c|c|c|c|c|c|c|}
\hline \multirow[t]{3}{*}{ FAMILY } & \multirow[t]{3}{*}{ SPECIES } & \multirow[t]{3}{*}{ FV } & \multirow[t]{3}{*}{$\mathrm{CS}$} & \multicolumn{4}{|c|}{ Forest stretch } \\
\hline & & & & \multicolumn{2}{|c|}{ Initial forest } & \multicolumn{2}{|c|}{ Advanced forest } \\
\hline & & & & $1^{\mathrm{a}}$ collect & $2^{\mathrm{a}}$ collect & $1^{\mathrm{a}}$ collect & $2^{a}$ collect \\
\hline ACANTHACEAE & Blechnum cf. brasiliensis & Her & - & 0 & 6 & 0 & 0 \\
\hline ANNONACEAE & Rollinia $\mathrm{sp}$ & Arv & SI & 1 & 0 & 0 & 0 \\
\hline \multirow[t]{26}{*}{ ASTERACEAE } & Ageratum conyzoides $\mathrm{L}$. & Her & - & 0 & 4 & 0 & 0 \\
\hline & Aster squamatus (Spreng.) Hieron & Her & - & 1 & 0 & 9 & 6 \\
\hline & Bacharis sp. & Abt & - & 4 & 6 & 1 & 5 \\
\hline & Conyza bonariensis (L.) Cronquist. & Her & - & 1 & 4 & 1 & 2 \\
\hline & Conyza canadensis (L.) Cronquist. & Her & - & 2 & 0 & 4 & 0 \\
\hline & Crepis japonica Benth. & Her & - & 2 & 20 & 0 & 8 \\
\hline & Emilia sonchifolia (L.) DC. & Her & - & 3 & 5 & 0 & 22 \\
\hline & Erechtites hieraciifolius (L.) & Her & - & 40 & 63 & 85 & 45 \\
\hline & Eupatorium maximilianii Schrad. & Her & - & 4 & 3 & 0 & 0 \\
\hline & Galinsoga quadriradiata Ruiz et Pav & Her & - & 1 & 0 & 1 & 0 \\
\hline & Gnaphalium pensylvanicum Willd. & Her & - & 0 & 4 & 0 & 12 \\
\hline & Hypochoeris radicata $\mathrm{L}$ & Her & - & 223 & 105 & 159 & 105 \\
\hline & Mikania hirsutissima DC. & Lia & - & 0 & 1 & 0 & 1 \\
\hline & Mikania cordifolia Willd & Lia & - & 14 & 18 & 1 & 13 \\
\hline & Mikania sp. & Lia & - & 70 & 21 & 1 & 0 \\
\hline & $\begin{array}{c}\text { Piptocarpha macropoda } \\
\text { (DC.) Baker }\end{array}$ & Arv & PI & 0 & 0 & 2 & 0 \\
\hline & Pterocaulon lanatum Kuntze & Her & - & 0 & 2 & 5 & 3 \\
\hline & Pterocaulon virgatum (L.) DC. & Her & - & 0 & 30 & 0 & 2 \\
\hline & Siegesbeckia orientalis (LINN.) & Her & - & 0 & 0 & 7 & 0 \\
\hline & Sonchus asper (L.) Hill & Her & - & 7 & 0 & 6 & 0 \\
\hline & Sonchus oleraceus L. & Her & - & 2 & 2 & 2 & 2 \\
\hline & Vernonia diffusa Less & Arv & PI & 0 & 0 & 4 & 1 \\
\hline & Vernonia polyanthes Less. & Abt & - & 9 & 7 & 7 & 4 \\
\hline & Species 1 & Her & - & 2 & 4 & 0 & 1 \\
\hline & Species 2 & Her & - & 1 & 0 & 0 & 0 \\
\hline & Species 3 & Abt & - & 0 & 0 & 1 & 0 \\
\hline BEGONEACEAE & Begonia cucullata Willd. & Her & - & 2 & 2 & 15 & 1 \\
\hline \multirow[t]{5}{*}{ BIGNONEACEAE } & Jacaranda cf. puberula Cham. & Arv & SI & 1 & 0 & 0 & 0 \\
\hline & Pyrostegia venusta Miers & Lia & - & 0 & 0 & 0 & 1 \\
\hline & Spathodea campanulata P. Beauv. & Arv & - & 1 & 2 & 4 & 14 \\
\hline & Species 1 & Arv & - & 0 & 0 & 1 & 0 \\
\hline & Species 2 & Lia & - & 0 & 1 & 0 & 0 \\
\hline BRASSICACEAE & Cardamine bonariensis L. & Her & - & 24 & 0 & 5 & 0 \\
\hline CANNACEAE & Trema micrantha (L.) Blum & Arv & PI & 43 & 17 & 11 & 5 \\
\hline CELESTRACEAE & Maytenus cf. aquifolia MAbt. & Arv & ST & 0 & 0 & 2 & 0 \\
\hline COMMELINACEAE & Commelina sp. & Her & - & 0 & 1 & 0 & 0 \\
\hline CUCUBITACEAE & Trianosperma trifoliolata Cogn. & Lia & - & 1 & 0 & 0 & 0 \\
\hline CYPERACEAE & Cyperus rotundus $\mathrm{L}$. & Her & - & 0 & 2 & 0 & 3 \\
\hline \multirow[t]{4}{*}{ EUPHORBIACEAE } & Acalypha communis Müll.Arg. & Her & - & 0 & 5 & 0 & 6 \\
\hline & Croton urucurana Baillon & Arv & PI & 17 & 2 & 2 & 1 \\
\hline & Phyllanthus tenellus Roxb. & Her & - & 2 & 3 & 5 & 1 \\
\hline & Species 1 & Lia & - & 0 & 1 & 0 & 0 \\
\hline
\end{tabular}

Revista Árvore, Viçosa-MG, v.40, n.3, p.415-425, 2016 
Table $1 \ldots$

Tabela 1...

\begin{tabular}{|c|c|c|c|c|c|c|c|}
\hline \multirow{5}{*}{ FABACEAE } & Apuleia leiocarpa (Vog.) & Arv & - & 2 & 0 & 0 & 0 \\
\hline & Indigofera $\mathrm{SP}$ & Abt & - & 0 & 0 & 0 & 2 \\
\hline & Crotalaria pallida Ait & Lia & - & 1 & 0 & 0 & 0 \\
\hline & Rhynchosia mínima (L.) DC. & Lia & - & 0 & 0 & 2 & 0 \\
\hline & $\begin{array}{c}\text { Desmodium adscendens } \\
\text { (Sw.) DC. }\end{array}$ & Her & - & 2 & 0 & 0 & 0 \\
\hline LAMIACEAE & Aegiphila sellowiana Cham. & Arv & P I & 2 & 2 & 0 & 0 \\
\hline LECYTHIDACEAE & $\begin{array}{c}\text { Cariniana estrellensis } \\
\text { (Raddi) Kuntez }\end{array}$ & Arv & ST & 0 & 0 & 1 & 0 \\
\hline LYTHRACEAE & $\begin{array}{l}\text { Cuphea Abthagenensis } \\
\text { (Jacq.) J.F.Macbr. }\end{array}$ & Her & - & 3 & 7 & 0 & 15 \\
\hline \multirow[t]{3}{*}{ MALVACEAE } & $\begin{array}{c}\text { Luehea grandiflora } \\
\text { MAbt. \& Zucc }\end{array}$ & Arv & SI & 0 & 0 & 1 & 0 \\
\hline & $\begin{array}{c}\text { Pseudobombax grandiflorum } \\
\text { (Cav.) A. Robyns }\end{array}$ & Arv & SI & 0 & 0 & 1 & 0 \\
\hline & Sida rhombifolia $\mathrm{L}$ & Her & - & 14 & 1 & 3 & 2 \\
\hline MARANTACEAE & $\begin{array}{c}\text { Maranta leuconeura } \\
\text { E. Morren }\end{array}$ & Her & - & 0 & 0 & 2 & 0 \\
\hline \multirow[t]{8}{*}{ MELASTOMATACEAE } & $\begin{array}{c}\text { Leandra purpurascens } \\
\text { (DC.) Cogn. }\end{array}$ & Abt & - & 14 & 4 & 85 & 72 \\
\hline & $\begin{array}{c}\text { Miconia cinnamomifolia } \\
\text { (DC.) Naud.) }\end{array}$ & Arv & PI & 18 & 4 & 26 & 5 \\
\hline & Miconia sp. 1 & Arv & - & 1 & 2 & 1 & 8 \\
\hline & Miconia sp.2 & Arv & - & 13 & 2 & 2 & 2 \\
\hline & Miconia sp 3 & Abt & - & 0 & 0 & 5 & 0 \\
\hline & Miconia sp. 4 & Abt & - & 0 & 0 & 10 & 0 \\
\hline & $\begin{array}{l}\text { Tibouchina granulosa } \\
\text { (Desr.) Cogn }\end{array}$ & Arv & PI & 1 & 2 & 1 & 1 \\
\hline & Species 1 & Arv & - & 1 & 1 & 0 & 0 \\
\hline MIRTACEAE & Species 1 & Arv & - & 0 & 0 & 2 & 0 \\
\hline MOLLUGINACEAE & Mollugo verticillata L. & Her & - & 1 & 0 & 0 & 0 \\
\hline OXALIDACEAE & Oxalis corniculata L. & Her & - & 35 & 42 & 40 & 54 \\
\hline \multirow[t]{2}{*}{ PASSIFLORACEAE } & Passiflora sp. & Lia & - & 1 & 0 & 0 & 0 \\
\hline & Passiflora cincinnata Mast. & Lia & - & 0 & 0 & 0 & 1 \\
\hline \multirow[t]{2}{*}{ PIPERACEAE } & $\begin{array}{c}\text { Piper claussenianum } \\
\text { (Miq.) C.DC. }\end{array}$ & Abt & - & 13 & 6 & 24 & 13 \\
\hline & $\begin{array}{c}\text { Pothomorphe umbellata } \\
\text { (L.) Miq }\end{array}$ & Abt & - & 28 & 4 & 36 & 9 \\
\hline PLANTAGINACEAE & Scoparia dulcis L. & Her & - & 4 & 6 & 0 & 0 \\
\hline \multirow[t]{4}{*}{ POACEAE } & $\begin{array}{c}\text { Brachiaria cf. subquadripara } \\
\text { (Trin.) Hitchc. }\end{array}$ & Her & - & 7 & 12 & 1 & 5 \\
\hline & Brachiaria sp. 1 & Her & - & 19 & 14 & 4 & 4 \\
\hline & Brachiaria sp. 2 & Her & - & 13 & 0 & 6 & 2 \\
\hline & Digitaria $\mathrm{sp}$ & Her & - & 5 & 9 & 2 & 8 \\
\hline ROSACEAE & Prunus sellowii Koehne. & Arv & ST & 3 & 1 & 3 & 1 \\
\hline ROSACEAE & Rubus rosifolius Smith & Lia & - & 2 & 3 & 3 & 8 \\
\hline \multirow[t]{4}{*}{ RUBIACEAE } & Chiococca alba (L.) Hitch & Abt & - & 0 & 0 & 1 & 0 \\
\hline & Palicourea marcgravii St. Hill. & Abt & - & 4 & 0 & 0 & 0 \\
\hline & Psychotria sessilis Vell. & Arv & ST & 1 & 0 & 4 & 0 \\
\hline & Spermacoce verticillata $\mathrm{L}$. & Her & - & 2 & 0 & 0 & 0 \\
\hline RUTACEAE & Zanthoxylum rhoifolium Lam. & Arv & ST & 0 & 0 & 0 & 1 \\
\hline SALICACEAE & Casearia sp. & Arv & SI & 0 & 0 & 1 & 0 \\
\hline SAPINDACEAE & Species 1 & Lia & - & 8 & 1 & 1 & 0 \\
\hline SCHIZAEACEAE & Lygodium volubile Sw. & Her & - & 37 & 0 & 0 & 0 \\
\hline
\end{tabular}


Table 1...

Tabela $1 .$.

\begin{tabular}{|c|c|c|c|c|c|c|c|}
\hline SCROPHULARIACEAE & $\begin{array}{l}\text { Buddleia brasiliensis } \\
\text { Jacq. Ex Spreng. }\end{array}$ & Her & - & 3 & 0 & 0 & 0 \\
\hline SIPARUNACEAE & Siparuna guianensis Aubl. & Arv & SI & 1 & 1 & 3 & 0 \\
\hline \multirow[t]{8}{*}{ SOLANACEAE } & Physalis pubescens L. & Her & - & 0 & 1 & 0 & 0 \\
\hline & Solanum americanum Mil. & Her & - & 15 & 46 & 16 & 27 \\
\hline & Solanum cernum Vell & Arv & PI & 3 & 1 & 3 & 2 \\
\hline & Solanum erianthum D.Don & Arv & PI & 2 & 0 & 5 & 7 \\
\hline & $\begin{array}{l}\text { Solanum cf. leucodendron } \\
\text { Sendt. }\end{array}$ & Arv & PI & 1 & 2 & 1 & 6 \\
\hline & Solanum paniculatum L. & Abt & - & 2 & 5 & 2 & 1 \\
\hline & $\begin{array}{l}\text { Vassobia breviflora } \\
\text { (Sendtn.) Hunz. }\end{array}$ & Arv & PI & 0 & 0 & 6 & 1 \\
\hline & Species 1 & Abt & - & 0 & 0 & 1 & 0 \\
\hline THELYPTERIDACEAE & $\begin{array}{l}\text { Thelypteris dentate } \\
\text { (Forssk.) E.P.St.John }\end{array}$ & Her & - & 0 & 0 & 0 & 20 \\
\hline \multirow[t]{2}{*}{ URTICACEAE } & Cecropia glaziovii Snethl. & Arv & PI & 0 & 4 & 4 & 1 \\
\hline & Cecropia hololeuca Miq. & Arv & PI & 47 & 12 & 59 & 21 \\
\hline VERBENACEAE & Lantana trifolia $\mathrm{L}$. & Abt & - & 0 & 2 & 0 & 0 \\
\hline VIOLACEAE & Anchietea salutaris A. St.-Hil. & Lia & - & 1 & 0 & 0 & 0 \\
\hline \multirow[t]{8}{*}{ INDETERMINADA } & Species 1 & Arv & - & 0 & 0 & 7 & 0 \\
\hline & Species 2 & Arv & - & 0 & 0 & 2 & 0 \\
\hline & Species 3 & Arv & - & 0 & 0 & 0 & 1 \\
\hline & Species 4 & Lia & - & 0 & 1 & 2 & 0 \\
\hline & Species5 & Lia & - & 1 & 0 & 1 & 1 \\
\hline & Species 6 & Lia & - & 3 & 0 & 1 & 0 \\
\hline & Species 7 & Lia & - & 2 & 0 & 0 & 0 \\
\hline & Species 8 & Lia & - & 9 & 0 & 0 & 0 \\
\hline TOTAL & & & & 823 & 539 & 722 & 565 \\
\hline
\end{tabular}

families, two unidentified and 86 individuals germinated in the bank of the rainy season were 16 species of nine families, a person remained unidentified (Table 1).

The species that stood out in number of individuals at the end of the seed bank of the dry season were Cecropia hololeuca (47), Trema micrantha (43) and Miconia cinnamomifolia (18) in the initial forest and C. hololeuca (59), Miconia cinnamomifolia (26) and T. micrantha (11) in advanced. At the end of the bank of the rainy season stood out $T$. micrantha (17) and C. hololeuca (12) in the initial forest and C. hololeuca (21) and Solanum erianthum (07) in advanced.

The successional classification of species sampled in seed banks of the two forest stretches analyzed is shown in Figure 2. The comparative graphs show a lot of pioneer species individuals in the forest stretches (initial and advanced).

The dendrogram view that the floristic relationships generated by cluster analysis using the group average (UPGMA), shows that the two major groups, one formed by the plots of the species sampled in 0.5 ha of forest and the other by the species germinated the seed bank of each of these plots showed low floristic similarity $(\mathrm{J} \leq 0.5)$ (Figure 3).

The greatest floristic similarity observed was among the seed banks of the plot four eight of the original forest, with Jaccard index showing a similarity of species of $79 \%$, followed by banks removed from portions 16:18 Advanced forest with observed similarity between the species of $75 \%$.

We observe also the formation of subgroups with the seed bank samples showing a large heterogeneity among banks stretches. The first subgroup formed between species showed similarity of $25 \%$ to $26 \%$ the second the third $27 \%$.

\section{DISCUSSION}

The results presented by the seed bank with the highest seed germination associated with the end of the dry season did not follow the pattern of temporal 

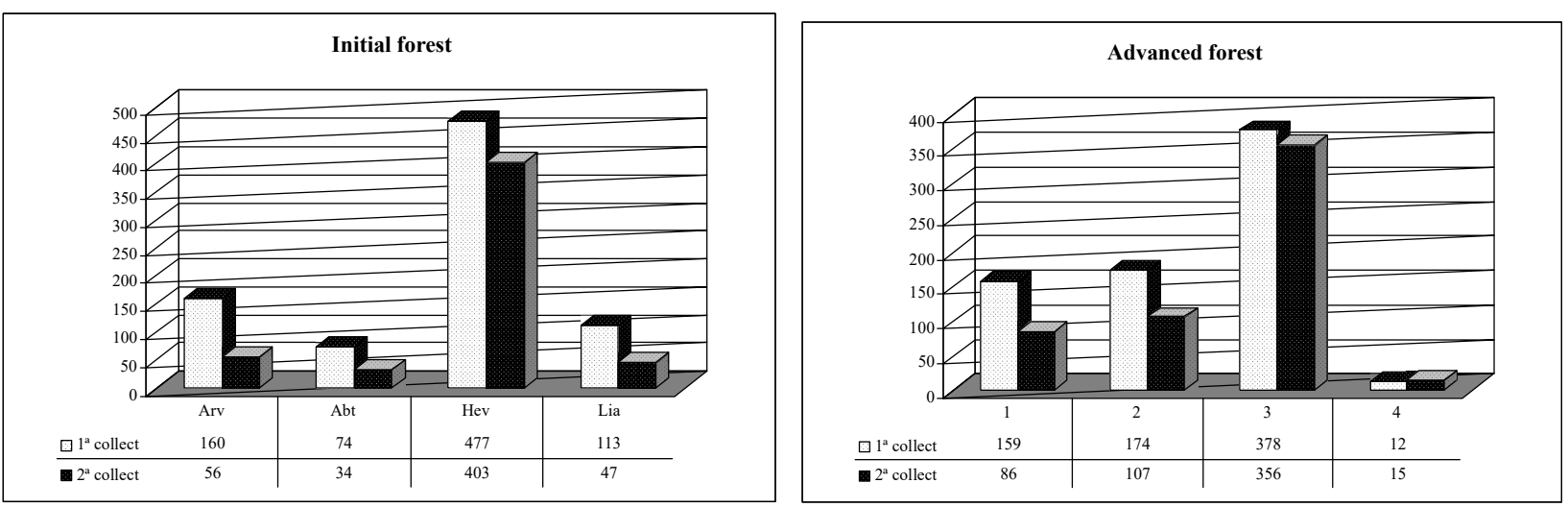

Figure 1 - Percentages of individuals by life forms sampled in the seed bank in drought station finish $\left(1^{\mathrm{a}}\right.$ collect $)$ and rainy station $\left(2^{\mathrm{a}}\right.$ collect $)$ of in the Mata da Agronomia in Viçosa, MG. Arv = tree; Abt. = shrub; Hev. $=$ herb and Lia $=$ liana.

Figura 1 - Porcentagens de indivíduos por forma de vida, amostradas no banco de sementes coletado no final da estação seca $\left(1^{a}\right.$ coleta $)$ e da estação chuvosa $\left(2^{a}\right.$ coleta $)$ em cada trecho da Mata Agronomia em Viçosa, MG. Arv = árvore; Abt = arbusto; Hev = herbácea e Lia=liana.
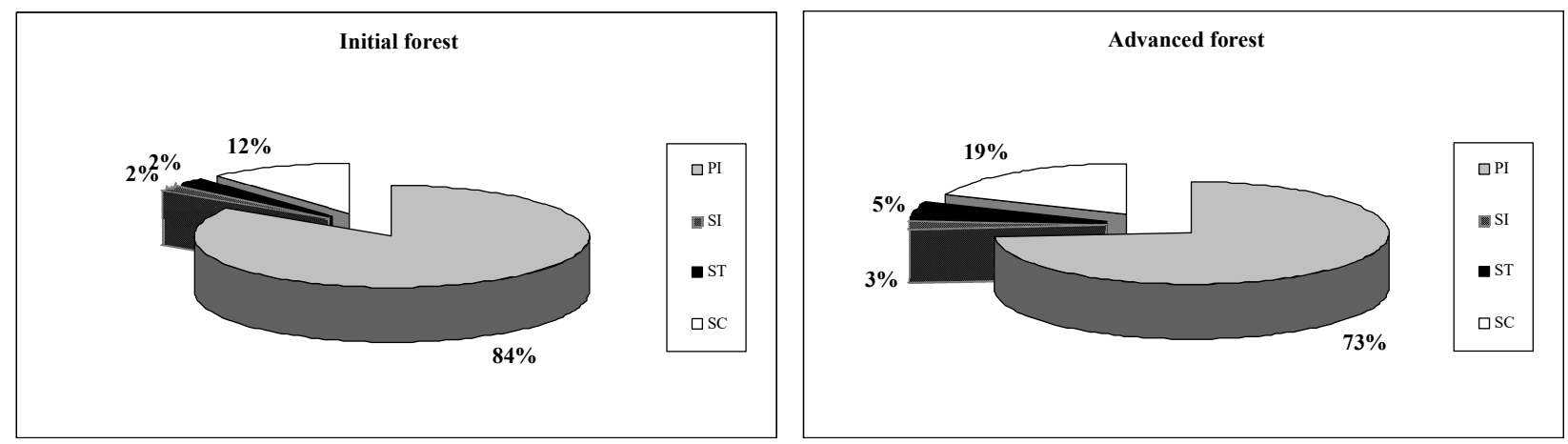

Figure 2 - Percentage of species by sucessional categories $(\mathrm{SC}=$ not classification; $\mathrm{PI}=$ pioneering, $\mathrm{SI}=$ initial secondary e ST = late secondary)sampled in the seed bank in each sites of Forest in Mata da Agronomia in Viçosa, MG, Brazil.

Figura 2 -Percentual de espécies por categoria sucessional $(S C=$ sem classificação, $P I=$ pioneira, $S I=$ secundária inicial e $S T$ = secundária tardia) amostradas nos bancos de sementes de cada trecho de floresta da Mata da Agronomia em Viçosa, MG, Brasil.

variation in seed production presented in the seed rain study in fragment (BRAGA et al., 2015) where the highest deposition occurred at the end of the rainy season in both stretches of forest.

However, we observed two production peaks in the initial forest of these at the end of the dry season between the months of September and October. This lack of synchrony can is related to factors such as seed dormancy that are produced at the station as an adaptive strategy to resist water stress period or even the impossibility of the same.
The predominance of herbaceous species and individuals as observed in this study was also recorded in the seed bank studied by Calegari et al. (2013), Martin et al. (2008), Souza et al. (2006), Costalonga et al. (2006) and Batista Neto et al. (2007). This predominance of herbaceous species is associated with bank disturbed areas of seeds, where factors such as dispersal mechanisms, size and seed dormancy, seed quantity, life cycle of the species, the absence or non-continuity of the canopy in the forest (facilitating entry and retention of the seeds in the soil), cooperating for such dominance (SOUZA et al., 2006; CALEGARI et al., 2013).

Revista Árvore, Viçosa-MG, v.40, n.3, p.415-425, 2016 


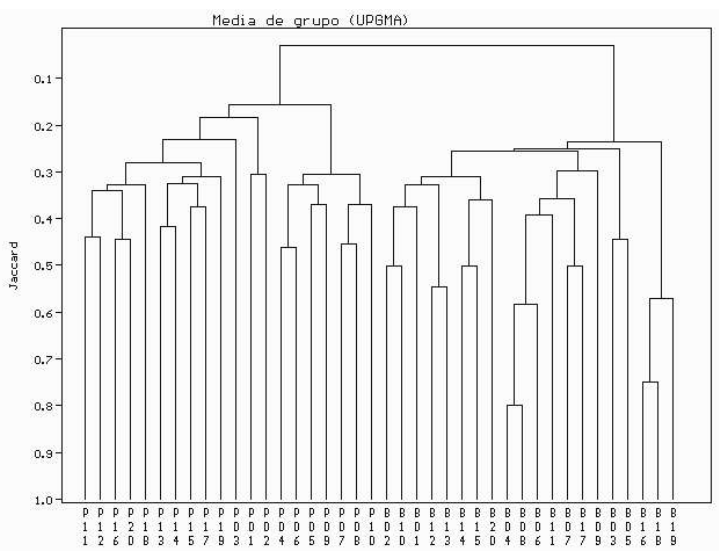

Figure 3 - Dendrogram obtained using Jaccard similarity index and average linkage method (UPGMA), for the presence and absence data of the species of initial forest (P01 to P10), advance (P11 to P20), the seed bank species of initial forest (B01 to B10)and the seed bank species of advance forest (B11 to B20) in the Mata da Agronomia, Viçosa/ MG

Figura 3 - Dendrograma obtido pelo método da média de grupo (UPGMA), com base no índice de Jaccard, para dados de presença e ausência das espécies das florestas inicial (P01 a P10), da avançada (P11 a P20), das espécies do banco de sementes da floresta inicial (BO1 a B10) e as espécies do banco da floresta avançada (B11 a B20) na Mata da Agronomia, Viçosa/MG.

When analyzing the seed bank studies on the lush region (SOUZA et al., 2006; BATISTA NETO et al., 2007; BRAGA et al., 2008) and in other locations in Zona da Mata Mineira (COSTALONGA et al, 2006; MARTINS et al., 2008; CALEGARI et al., 2013), it is observed that the Asteraceae family always stands out with the highest number of species compared with other botanical families, with the particularity of most germinated individuals are herbaceous, way of life considered invasive crops and pastures. The dominance of the family, among the richest specifies remain even after the seed bank to be impacted by fire (CAMARGOS et al., 2013).

A bank of rich seeds in invasive plant species before a natural or anthropogenic disturbance, with the opening of clearings, could become a problem, to colonize the area, compete with native species and affect the sustainability of the ecosystem (MARTINS, 2001; CALEGARI et al., 2013). As happened in the plots (07-10 initial forest) dominated by species of lianas, the presence of individual trees was comparatively fewer, warning of possible need for monitoring and interventions in case of change or serious disorders through proper management of area for the advancement of succession.

Interestingly, the germination of liana individuals in the initial forest was higher in the corresponding seed bank at the end of the dry season, a period in which there is increased production of lianas seed as seed rain study data conducted in this patch of forest (BRAGA, et al., 2015). Therefore, the presence of lianas this more associated with initial forest seed banks, which are sometimes responsible for the suppression of plant community, inhibiting or stagnating successional advance.

However, the presence of such species in the initial seed bank does not show its full fragility, because mostly the bank is formed by herbaceous species that has no actual damage to the advancement of succession. Allied to this, the large number of individual trees and shrubs present in the Agronomy Forest's seed bank, especially in the advanced patch of forest, shows the dynamic role of the bank and ensures its self-sustaining regenerative function.

The number of individual trees sprouted at the end of the rainy season was much lower than germinated number at the end of the dry season, probably as the environment adaptive strategy, considering that in the period, the water deficit in the habitat hinder the development and establishment of certain species decreasing the population of those in the community. Note also change the species with the highest number of individuals with the evaluation period. As noted in the species C. hololeuca, T. micrantha and Miconia cinnamomifolia, which always constitute among the most abundant in studies of seed bank in the region (SOUZA et al., 2006; BRAGA et al., 2008; FRANCO et al., 2012), had germination peak in the seed bank collected at the end of the dry season.

Importantly the presence always especially of $C$. hololeuca of individuals that occurred in most samples of the seed bank plots despite the low density of adults in the area, one in the first portion of the original forest. The high density of individuals of that species in the bank can be justified by the long-range dispersal of species of seeds evidenced by seed rain study in the forest (BRAGA et al., 2015). 
Although the successional classification of tree species sampled in the seed bank in both stretches of forest (initial and advanced) point a number of germinated pioneering individuals much higher than of late, it was observed in advanced forest seed bank, a decrease the percentage of pioneering individuals and a slight increase in the percentage of individuals of species classified as late. This fact can be explained by the deposition of seeds in scattered bank of local floristic individuals, as Cariniana estrellensis, Jacaranda cf. puberula, Maytenus cf. aquifolia, Psychotria sessilis, Siparuna guianensis, Zanthoxylum rhoifolium, among others.

The heterogeneity observed between the banks of seeds collected in the forest plots may result from changes in the fragment of seed rain, such as the dispersal of seeds, own environmental conditions at the time of deposition and germination of viable seeds, in addition to other factors ranging from the topographic profile to the very successional stage of the forest. According to Machado et al. (2004), heterogeneity should be taken into consideration when looking for ways to conserve biological diversity of forest remnants.

\section{CONCLUSION}

The potential germination of seeds present in the fragment of the seed bank was higher at the beginning of the rainy season and this seed bank in the initial forest.

The form of herbaceous life predominated among individuals germinated from the seed bank. Fact that does not threaten the successional dynamics of forest ecosystems, due to the large number of tree and shrub individuals also germinated and low density of herbaceous competing individuals.

Seed germination of ecological group of pioneer species prevailed in both successional stages of seasonal forest fragment Semidecidual ascertained. It was found also a significant germination of late species seeds in advanced patch of forest, important event for the ecological dynamics of the ecosystem in question.

The similarity index showed that current floristic community forest fragment had low contribution to the seed bank of this ecosystem. This index also showed greater similarities between the banks collected in nearby portions of the same stretch of forest. Therefore, the ecosystem the greatest contributions to the bank are seeds of species that once populated the stretch, pioneers, or dispersed seeds from neighboring fragments.

\section{REFERENCES}

ANGIOSPERM PHYLOGENY GROUP II. An update of the Angiosperm Phylogeny Group classification for the orders and families of flowering plant: APG II. Botanical Journal of the Linnaean Society, v.141, n.4, p.399-436, 2003.

ARAÚJO, M.M.; OLIVEIRA, F.A.; VIEIRA, I.C.G.; BARROS, P.L.C.; LIMA, C.A.T. Density and floristic composition of the soil seed bank in the successional forests in Lower Guama River region, Eastern Amazonian. Scientia Florestalis, v.59, n.9, p.115-130, 2001.

BATISTA NETO, J.P.; REIS, M.G.F.; REIS, G.G.; SILVA, A.F.; CACAU, F.V. Soil seed bank in a semideciduous seasonal forest, in Viçosa, Minas Gerais. Ciência Florestal, v.17, n.4, p.311$320,2007$.

BRAGA, A.J.T.; BORGES, E.E.L.; MARTINS, S.V. Seed rain in successional stages of semideciduous seasonal forest in Viçosa, MG. Revista Árvore, v.39, n.3, p.475-485, 2015.

BRAGA, A.J.T.; BORGES, E.E.L.; MARTINS, S.V. Floristic and structure of tree community in secondary semideciduous seasonal forest in Viçosa, MG. Revista Árvore, v.35, n.3, p.493503, 2011.

BRAGA, A.J.T.; GRIFFITH, J.J.; PAIVA, H.N.; MEIRA-NETO, J.A.A. Composition of a secundary forest seed bank considering its potential use for environmental reclamation. Revista Árvore, v.32, n.6, p.1089-1098, 2008.

BRAGA, A.J.T.; GRIFFITH, J.J.; PAIVA, H.N.; SILVA, F.C.; CORTE, V.B.; MEIRA NETO, J.A.A.M. Litter-soil system enrtichment with tree species suitable for diturbed land reclamation. Revista Árvore, v.31, n.6, p.1145-1154, 2007.

CALEGARI, L.; MARTINS, S.V.; CAMPOS, L.C.; SILVA, E.; GLERIANI, J.M. Evaluation of soil seeds bank for forest restoration in Carandaí, MG. Revista Árvore, v.37, n.5, p.871-880, 2013.

Revista Árvore, Viçosa-MG, v.40, n.3, p.415-425, 2016

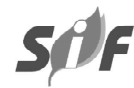


CAMARGOS, V.L.; MARTINS, S.V.; RIBEIRO, G.A.; CARMO, F.M.S.; SILVA, A.F. The influence of fire on the soil seed bank in semideciduous forest. Ciência Florestal, v.23, n.1, p.19-28, 2013.

CASTRO, P.S.;VALENTE, D.F.; COELHO, D.F.; RAMALHO, R.S. Rain interception by natural secondary forest in Viçosa, MG. Revista Árvore, v.7, p.76-9, 1983.

CORRÊA, G.F. Evolution model and clay mineralogy of soils Viçosa Planalto. 1983. 87f. Dissertação (Mestrado em Solos e Nutrição de Plantas) - Universidade Federal de Viçosa, Viçosa, MG: 1983.

COSTALONGA, S.R.; REIS, G.G.; REIS, M.G.F.; SILVA, A.F.; BORGES, E.E.L.; GUIMARÃES, F.P. Soil seed bank floristic in a contiguous area of degraded pasture, eucalypt plantation and forest. Floresta, v.36, n.2, p.239-250,2006.

FRANCO, B.K.S.; MARTINS, S.V.; FARIA, P.C.L.; RIBEIRO, G.A. Density and floristic composition of the semideciduous seasonal forest stretch seed bank, located in the campus of Viçosa Federal University, MG, Brazil.

Revista Árvore, v.36, n.3, p.423-432, 2012.

GANDOLFI, S.; LEITÃO FILHO, H.F.; BEZERRA, C.L.F. Floristic Survey and Succession of Shrub and Tree Species of One Mesophytic Semideciduous Forest in the Guarulhos Municipality, SP. Revista Brasileira de Biologia, v.55, n.4, p.753767, 1995.

GARDWOOD, N.C. Tropical soil seed banks: a review. In: LECK, M.; PARKER, V.; SIMPSON, R. (Ed.). Ecology of soil seed banks. San Diego: Academic Press, 1989. p.149-209.

HALL, J.B.; SWAINE, M.B. Seed stocks in Ghanaian forest soil. Biotropica, v.12, n.1, p.256-263, 1980 .

HARPER, J.L. Population biology of plants. London: Academic Press, 1977. 892p.

JOLY, C.A. Environmental heterogeneity and diversity of adaptive strategies of tree species gallery forest. In: SYMPOSIUM ANNUAL SAO

Revista Árvore, Viçosa-MG, v.40, n.3, p.415-425, 2016
PAULO SCIENCE ACADEMY - Perspectives of Theoretical Ecology, 10., 1986, São Paulo. Anais...São Paulo: ACIESP, 1986. p.19-38.

LONGHI, S.J.; BRUN, E.J.; OLIVEIRA, D.M.; FIALHO, L.E.B.; WOJCIECHOWSKI, J.C.; VACCARO, S. Soil seed bank of three sucessional phases in a seasonal deciduous forest in SANTA TEREZA, RS. Ciência Florestal, v. 15, n.4, p.359-370, 2005.

MACHADO, E.L.M.; OLIVEIRA-FILHO, A.T.; CARVALHO, W.A.C.; SOUZA, J.S.; BORÉM, R.A.T.; BOTEZELLI, L. A comparative analysis of the structure and flora of the tree-shrub compartment from a remnant forest at Fazenda Beira Lago, Lavras, MG, Brazil. Revista Árvore, v.28, n.4, p.499-516, 2004.

MARTINS, S.V. Recuperação de matas ciliares. Viçosa, MG: Aprenda Fácil, 2001. $146 \mathrm{p}$.

MARTINS, S.V.; PELLEGRINI, M.C.; MARANGON, L.C. Structure and floristic composition of a secondary forest in CruzeiroSP. Revista Árvore, v.26, n.1, p.35-41, 2002.

MARTINS, S.V.; ALMEIDA, D.P.; FERNANDES, L.V.; RIBEIRO, T.M. Seed bank as indicator of restoration of a kaolin mining - degraded area in BRÁS PIRES, MG. Revista Árvore, v.32, n.6, p.1081-1088, 2008.

MARTINS, S.V.; RODRIGUES, R.R. Gap-phase regeneration in a semideciduous mesophytic forest, south-eastern Brazil. Plant Ecology, v.163, p.51-62, 2002.

MUELLER-DOMBOIS, D; ELLENBERG, $\mathrm{H}$. Aims and methods of vegetation ecology. New York: John Wiley \& Sons, 1974. $547 \mathrm{p}$.

PIELOU, E.C. Ecological diversity. New York: John Wiley e Sons, 1975. 165p.

SCHMITZ, M.C. Banco de sementes no solo em áreas do reservatório da UHE Paraibuna. In: KAGEYAMA, P.Y. Recomposição da vegetação com espécies arbóreas nativas em reservatórios de usinas hidrelétricas da CESP. IPEF, v. 8, n.25, p.7-8, 1992 . 
SHEPHERD, G.J. Fitopac 1.0: user manual. Campinas: Departamento de Botânica, UNICAMP, 1996. 89p.

SOUZA, P.A.; VENTURIN, N.; GRIFFITH, J.J.; MARTINS, S.V. Evaluation of a seed bank contained in the litter of a forest fragment envisaging the recovery of degraded areas. Revista Cerne, v.12, n.1, p.56-67, 2006.

VELOSO, H.P.; RANGEL-FILHO, A.L.R.; LIMA, J.C.A. Classificação da vegetação brasileira adaptada a um sistema universal. Rio de Janeiro: IBGE, 1991. 123p. 